\title{
Hoax News: Promoting the Students' Critical Thinking in Critical Reading Class
}

\author{
Sri Haryati ${ }^{1}$ \\ English Education Department, Sebelas Maret University \\ Email: nafisahatiku@gmail.com \\ Diyah Nur Hidayati ${ }^{2}$ \\ Language Center, Sebelas Maret University \\ Email: diyah.nurhidayati26@yahoo.co.id \\ http://dx.doi.org/10.18326/rgt.v10i2.122-139
}

Submission
Track:
Received:
01-08-2017
Final Revision:
23-11-2017
Available online:
O1-12-2017

\section{ENGLISH ABSTRACT}

Critical thinking is vital for graduates in facing the dynamic life in order to strengthen their analysis ability and providing alternative solution towards the current problem. It is essential that units, courses, and material teach the critical thinking process have to provide an opportunity for students to excoriate certain problem and present the harmonious flow of thinking. Hoax news, the trending issue in a society as the reading materials, has abundance aspect to be criticized by students. Moreover, it has its own authenticity to be brought into a critical reading class as authentic materials which was not broadly discussed yet. This study aimed at paving the ways to improve the students' critical thinking skills through reading hoax news. It is conducted to investigate the usage of hoax news in teaching critical reading for undergraduate students as well as particularize how far hoax news can enhance studenst' critical thinking. This study employed classroom action research design. The subject of the study was the 31 students joining the critical reading class. The data were gotten from observation, document analysis and test. The essay test was the instrument used to assess the students' critical thinking which later adopted the model of the Holistic Critical Thinking Scoring Rubric (HCTSR). The result of the study showed that using of hoax news significantly improve the students' critical thinking followed by the development of interpretation, analysis and identification ability. The number students posed strong thinking increased from $6.45 \%$ to $72,2 \%$. Using critical thinking can promote students' high order thinking since it drives students to consider the fact and fake which demanding the high analysis and deep interpretation toward the presented text.

Keywords: Critical thinking, hoax news, teaching materials. 


\section{INDONESIAN ABSTRACT}

Berpikir kritis merupakan hal yang penting dalam mengahadapi hidup yang dinamis untuk memperkuat kemampuan analisis serta memberikan alternatif solusi dalam memecahkan masalah yang dihadapi saat ini. Sangatlah penting dalam setiap unit pembelajaran, perkuliahan dan materi mengajarkan proses berpikir kritis untuk menyiapkan siswa dalam menghadapi berbagai masalah dan merepresentasikan pemikiran secara runtut. Hoax News (Berita Hoax), permasalahan aktual di masyarakat, sebagai bahan bacaan menyuguhkan berbagai aspek untuk siswa kritisi. Terlebih, berita hoak mempunyai nilai autentik untuk dapat digunakan di kelas critical reading sebagai materi otentik yang belum banyak dibahas. Penelitian ini bertujuan untuk mengungkapkan cara meningkatkan berpikir kritis siswa dengan menggunakan hoax news sebagai bahan bacaan. Selain itu, penelitian ini berupaya mengungkap penggunaan berita hoak dalam mengajarkan kritikal reading bagi siswa serta mengetahui seberapa jauh berita hoal dapat meningkatkan kemampuan berpikir kritis siswa. Penelitian ini menggunakan desain penelitian tindakan kelas. Data diperoleh dari observasi, analisis dokumen dan tes. Tes berbentuk uraian (essay) merupakan instrumen penelitian yang digunakan untuk mengukur tingkat berpikir kritis siswa yang mana rubric penilaian model Holistic Critical Thinking Scoring Rubric (HCTSR) diadopsi untuk keperluan ini. Pengamatan juga dilakukan untuk mendukung perolehan data dalam penelitian ini. Hasil penelitian menunjukkan bahwa penggunaan hoax news secara signifikan dapat meningkatkan tingkat berpikir kritis siswa yang diikuti dengan meningkatnya kemampuan interpretasi, analisis dan identifikasi. Jumlah siswa yang memiliki kemampuan berpikir kritis yang kuat meningkat dari $6.45 \%$ menjadi $72,2 \%$. Menggunakan berita hoak dapat meningkatkan kemampuan berpikir kritis karena materi ini memacu siswa untuk berpikir kritis dan melakukan analisa mendalam pada teks yang disajikan.

Kata kunci: berfikir kritis, berita Hoax, materi mengajar

\section{INTRODUCTION}

Preparing university students to be competitive in the 21 st century needs critical thinking (Zivkovic, 2016). Critical thinking is the use of cognitives skills or strategies that increase the probability of a desireable outcome. It is purposeful, reasoned, and goal-directed. It is the kind of thinking involved in solving problems. Formulating inferences, calculating likelihoods, and making decisions. Critical thinkers use these skills appropriately, without 
promting, and usually with concious intents, in a variety setting. That is, they are predisposed to think critically. When think critically, we are evaluating the outcomes of our thought processes-how good a decision is or how well a problem solved (Halpern in Alnofaie, 2013).

The critical thinking as the heart of the key focus of university requires students to be not only smart but also creative, innovative, and communicative. They need to develop their critical thinking to share their ideas in order to be accepted by others. Indeed, sharing ideas do not solely say what they think (Wilson, 2016). They have to explain their judgment based on the evidence. Moreover, applying critical thinking in the university curriculum could be the tool of students' future success (Wilson, 2016). It is because the students who have a high critical thinking are able to open new perspectives, events, situations, and people from different angles (Akkaya 2012).

As a result, using a critical thinking in a critical reading class would be the best practice of this skill. The fact that most students in the university just read and/or learn the surface of the learning subject without find beyond it is also able to be the essential reason. Also, what students think recently is just solely how to get the high score without realizing the needs of learning essences itself. In fact, they need to learn how to analyze, justify, and judge using strong arguments in which those are parts of critical thinking skills. Those skills promote students to think beyond the limit.

In relation to the critical reading class, it becomes one of the compulsory subjects offered in the university. Based on the syllabus, the aims of this course are to comprehend ideas in and beyond the text. In this course, students are asked to identify characteristics of critical thinking, comprehend explicitly reading texts, and identify characteristics of texts including language function and contents. To achieve the goal, therefore, critical thinking is applied in this course.

The instructional process under critical reading class is expected to be able to facilitate the tertiery students' critical thinking betterment through reading the qualified reading materials. However, as a matter of fact, the level of students' critical reading shows that there were few students owning the strong critical thiking level. Only 6.45\% students (10 among 31 students) performed their strong critical thinking in perceiving the text. The rest of the students were put in unacceptable and acceptable level of thinking. The possible causal factor 
of the above problem was the choice of reading materials which was not sufficiently led students' to think more critically towards the content of the text.

Practically, there is still debatable what kind of appropriate materials and/or methods is used to teach critical thinking since teaching this thinking needs to engage teachers to be informative intellectual (Zivcovic, 2016). The teachers have to provide a relevant material promoting students to construct the knowledge as well as be active participants. Also, the teachers need to give a model how to apply the critical thinking skills to students.

To full fill this gap, hoax news is chosen to be a learning material to promote students' critical thinking in this study. This news consists of unsolvable-ideas which are believed to be able to encourage students' to think critically since students can share their opinion when criticizing it. In addition, the news is categorized as an authentic material that is able to use as a good learning source in the teaching and learning process. The debatable trending news is chosen to be categorized as hoax news by determining the flawed arguments stated in the news or providing the stronger argument to prove that the given news is hoax. Using this material, the students' ability for interpreting, identifying, analyzing, evaluating, justifying and explaining the arguments or opinion in the text are expected to develop.

Obviously, this study aimed at paving the ways to improve the students' critical thinking skills through reading hoax news in a critical reading class. Promoting students' critical thinking in a critical reading class is an uneasy job. It needs teachers' competence in determining the class' activity to stimulate the students' ways of thinking. Moreover, the teacher also needs to prepare the appropriate materials in order that the goal achieves successfully. Then, using hoax news, it is believed that the news is appropriate to be used to facilitate students when applying the critical thinking skills in the critical reading class due to several reasons discussed in the literature reviews. To know whether the students' critical thinking skills improve or not, the teacher, then, is able to use the Holistic Critical Thinking Scoring Rubric (HTCSR) proposed by Facione and Facione (1994).

This study is worthy to be done as there are few previous researchers discussed this topic in their study. Moreover, the application of critical thinking for teaching and learning foreign language is a new area of investigation. Critical thinking pedagogies are underpinned by the theory of critical language awareness. This theory explains the role of the learners' cognitives and metacognitive domains in developing his awareness of the new language and 
the world around him (Fairclough in Alnofaie, 2013). This work then proposed alternate teaching material for promoting students' critical thinking in reading class.

\section{Critical Thinking in the Classroom}

Talking about critical thinking, Freeley and Steinberg (2009) define as the ability to analyze, criticize, judge, and advocate clear ideas using inductive and/or deductive arguments. The ideas presented must be rational and logical. To make clear the explanation, mindful communication, problem-solving, and a freedom from bias or egocentric tendency are the keys of critical thinking. On the other word, Ennis (2011) stated critical thinking as the ability to provide, evaluate, state, deduce, and induce the problems. Both arguments are in accordance with Hervas's and Miralles's (2004) opinions. They state that critical thinking is required dynamic skills such as 'analyzing, conceptualizing, informing, managing, systemic thinking, and researching' to solve the problems. Everything stated must be based on the valid evidence.

The result of the research done by Zivkovic (2016) related to 'critical thinking' as an important attribute for success in $21^{\text {st }}$ century' shows that critical thinking is able to 1) encourage students to participate actively in the classroom, 2) acquire interpersonal and oral communication skills, and 3) develop better understanding of the issues at hand. Using critical thinking also overcome sociocultural obstacles and demonstrates students to engage successfully in group conversations in a critical dialogue (DeWaelsche, 2015). Particularly, critical thinking scaffolds students to 'develop deeper skills and criticality' (Wilson, 2015). Students who have strong critical thinking will be 'critical meaning-makers'. To make a good decision with a good reasoned and ethical argument needs critical thinking. Breaking argumentation down to get the validity and strength required a deep evaluation. Indeed, a critical thinker is better users of information. National Council Excellence in Critical Thinking Instruction (Michael Scriven and Richard Paul) argues that the effective critical thinkers are able to:

1. raise vital questions and problems, formulating them clearly and precisely,

2. gathers and assesses relevant information, using abstract ideas to interpret it effectively,

3. come to well-reasoned conclusions and solutions, testing them against relevant criteria and standards, 
4. think open-mindedly within alternative systems of thought, recognizing and assessing, as need be, their assumptions, implications, and practical consequences,

5. Communicate effectively with others in figuring out solutions to complex problems.

Overall, it could be concluded that critical thinking is very important because life demands decision making. The ability to make reasoned decisions relies on it as well. As critical thinkers, the learners need to share their strong analysis and evaluation of arguments based on the evidence they have. Moreover, the use of information and advocacy are also required in this skill. In the education field, it is very crucial to teach and learn critical thinking in order that students could be an open-minded person. This will help them to achieve their future dream in this era. Then, improving critical thinking could be learned by analyzing hot news in the recent day. Students analyze the case by using the principles of critical thinking.

\section{Critical Reading in a Critical Reading Course}

Critical reading is totally different from reading in common. This activity needs a high intelligence of thinking involving the critics of hidden analysis beyond the text (Valerio, 2013). It not only requires the linguistic related to the language used but also cultural levels (Wallace, 2003 in Valerio, 2013). Identifying cultural levels means that the readers have to know the implied meaning of the text regarding different cultures. Haromi (2014) also argues that critical reading is beyond understanding the explicit meaning of the text. He explains that it is in relation to the ability to:

1. create an accurate interpretation,

2. assess the author's purpose,

3. accurately identify the question-at-issue or the problem being discussed,

4. accurately identify basic concepts at the heart of what is written,

5. see significant implications of the advanced position,

6. identify, understand and evaluate the assumptions underlying someone's position,

7. recognize evidence, argument, inference (or their lack) in a written presentation,

8. reasonably assess the credibility of an author,

9. accurately grasp the point of view of the author,

10. empathetically reason within the point of view of the author.

Furthermore, Akine, et.al (2015) explains the different concept of basic reading skills and critical reading. The basic reading just needs the ability to analyze the main idea of the paragraph, multi-paragraph units and articles, text organizations, and transitions. On the other 
hand, the critical reading is related to the ability to identify the inference, analyzing stated implied the main idea, synthesizing the sentences, distinguishing fact and opinion, explaining figurative language, and identifying fallacies and emotional appeals. Those explanations are in line with Knott's opinion (2013 in Duran and Yalcintas, 2015) stating that it is not only finding the information but also thinking beyond the text. Indeed, evaluating and drawing the inferences is the key to critical reading.

Accordingly, applying critical thinking skills in the critical reading class is appropriate. Students need to employ the skills when analyzing the texts being discussed. Indeed, the analysis should be based on the strong evidence. Having a discussion with others will also be meaningful through the actual-based judgment. In this case, the critical thinking skills play an important role.

\section{Hoax News}

It is undeniable that a hoax always refers to a negative perception bringing some definition related to 'fakes, lies, frauds, and pranks. Whereas, Boese (2010) states that a hoax is 'deliberately deceptive act succeeding in capturing the attention of the public'. Rubin, et.al (2015) also point out that a hoax is 'deliberate fabrication or falsification' used to deceive the readers related to the news. Additionally, the plot of a hoax is made intentionally (Erlich, Flexner, Carruth and Hawkins, 1986). In fact, the hoax is used to cause embarrassment, or to provoke social or political change. It is also used to break individual or group reputation down (Paul in Pike, 2005). Then, frauds and pranks can become a hoax if those generate enough public impact (Boese, 2010). A lie categorizing a hoax must be outrageous, ingenious, dramatic, or sensational. Accurately, a large-scale hoax is 'creative, unique, and multiplatform' employing ‘beyond text analytics' (Rubin, et.al.,2015).

Regarding hoax news, Allcott and Gentzkow (2017) define it as 'intentionally fabricated news articles' that are able to mislead the readers. It means that the news is made and spread intentionally in accordance with the hidden goals. In addition, they explain the detail definition of hoax news into:

1) unintentional reporting mistakes;

2) rumors that do not originate from a particular news article;

3) conspiracy theories (these are, by definition, difficult to verify as true or false, and they are typically originated by people who believe them to be true); 
4) satire that is unlikely to be misconstrued as factual;

5) false statements by politicians;

6) reports that are slanted or misleading but not outright false.

Hoax news spreads mostly through media socials, especially Facebook (Menczer, 2016 in Lazer. et.al., 2017) since it is the ease of sharing and rewiring the social connections. Indeed, the young people as an active user tend to use this media than any other media. To support the statement, the reviews done by Allcott and Gentzkow (2017) also show that: (1) $62 \%$ of US adults get news on social media (Gottfried and Shearer 2016); (2) the most popular fake news stories were more widely shared on Facebook than the most popular mainstream news stories (Silverman 2016); (3) many people who see fake news stories report that they believe them (Silverman and Singer-Vine, 2016).

Analyzing the fact of hoax news, thus, a reader must be a smart and critical reader to deal with it. The reader needs to check and investigate the news rather than merely trust the way it is (Aryunia \& Aditomo, 2017 and Keeshin, 2009). In this case, critical thinking skills must be applied so that the news is able to validate using the strong analysis.

\section{Hoax News as Teaching Materials in Critical Reading Class}

The National Literacy Trust (2017) states that an incredible discussion regarding to hoax news as teaching materials comes up to students' critical literacy skills (www.theguardian.com). It is believed that students are able to develop their critical analysis using the news. Indeed, they are facilitated to share their ideas from different perspective to discuss the news in a safe place with the teacher's guidance.

In addition, Hobbs and McGee (2014) who concern on propaganda news pinpoint that the news can be a good teaching material since it strengthens students' belief in democracy. The more they analyze the idea, the more they appreciate the political, economic, and social freedom.

Zalaznick (2017) also shows a positive result for his research related to the hoax news in the class. Based on his interview with Camhi, the hoax news is able to (1) develop students' ability to evaluate the news, (2) teach students not only to be a good reader but also to be thinkers, (3) help students to consider all sides of an issue, and (4) teach students to make comparisons to their own lives, to figure out what the authors are trying to teach and what their bias is. 
Furthermore, Stockslader (in Zalaznick, 2017) says that the students' abilities to make valid inferences improve much better using the hoax news. They also can make connections between today's news and historical events. Gertler (in Zalaznick, 2017) adds that these sources of informational text can move students from the basics of reading comprehension to the higher-order, evaluative skills critical thinking skill.

\section{METHODS}

This study was conducted under collaborative classroom action research which applied planning, acting, observing and reflecting. It is a systematic inquiry with the goal of informing practice in a particular situation (Angelo and Cross, 1993, p. 1). This study aims at describing the learning process on an environment course when hoax news implemented in the critical reading class to promote the students' critical thinking as well as investigating how far those reading materials can improve this ability. The course is aim at comprehending ideas in and beyond the text. In this course, students are asked to identify characteristics of critical thinking, comprehend explicitly reading texts, and identify characteristics of texts including language function and contents.

Thirty-one students consisting six boys and twenty-five students in critical reading class for the fourth semester, a lecture and an observer involved in this study. The students' joined critical reading class as the continuation of the extensive reading class. The lecture and the observer worked together as the raters to achive the valid score of the students' critical thinking.

The focus of using hoax news containing current controversial and sensational issue in critical reading class was to promote the students' critical thinking ability. This ability was measured before and after the hoax news used in their class through pre-test and post-test. The instrument used to measure the students' critical thinking ability was an essay test which requires the students' ability to provide the argument, to evaluate, to state problems, to deduce, and to induce (Ennis, 2011). The Holistic Critical Thinking Scoring Rubric (HTCSR) by Facione and Facione (1994) used for assigning a rating to one to four levels ranging from strong to weak critical thinking. The HTCSR is chosen to anallitically put the students' level of critical thinking through several criteria. The data on the learning process obtained from 
the observation sheet recorded during the instructional process in 7 meetings ( 2 cycles) to depict the implementation of hoax news in critical reading class.

The cyclical procedures of action research covering planning, acting, observing and reflecting proposed by Kemmis and Mc Taggart (1992) is adopted in this study. The planning, the usage of hoax news in CR class, was setted before followed with the implementation of the planning. The observation was undergone later and the action together with the result were reflected to find out the betterments and the weaknesses of the action which was repaired in the next cycle. The spiral model of action research is visualized in figure 1.

Figure 1. The Procedure of Action Research

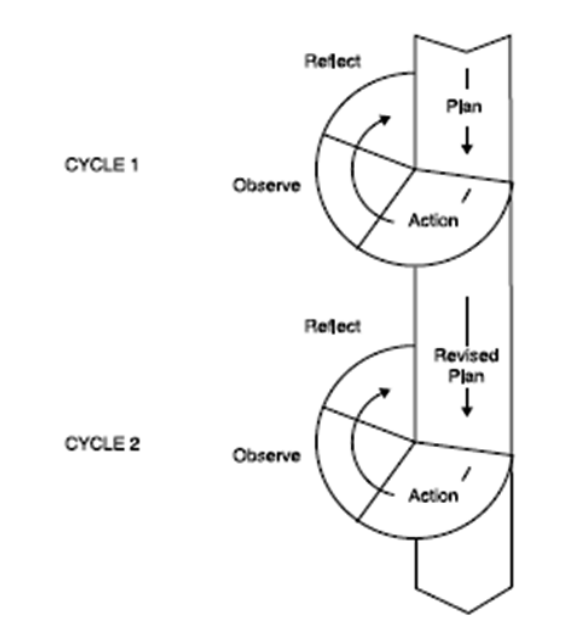

(Kemmis and Mc. Taggart, 1992)

The data obtained in this study were the students' critical thinking ability which categorized into four level and the learning process when hoax news used as the reading materials. The data of the students' critical thinking was gotten from pre-test and post-test. The HTCSR adopted in this study is presented in Table 1. The data of the students' critical thinking were analyzed descriptively and were presented, whereas the data of the learning process were obtained from an observation form during the instructional process when hoax news as the teaching aids used. 
Table 1. Scoring Rubric

\begin{tabular}{cl}
\hline Score & \multicolumn{1}{c}{ Criteria } \\
\hline 1 & Offers biased interpretations of evidence, statements, graphics, questions, \\
(Significantly & information, or the points of view of others. \\
Weak) & Fails to identify or hastily dismisses strong, relevant counter-arguments. \\
& Ignores or superficially evaluates obvious alternative points of view. \\
& Argues using fallacious or irrelevant reasons, and unwarranted claims. \\
& Does not justify results or procedures, nor explain reasons. \\
& Regardless of the evidence or reasons, maintains or defends views based \\
& on self-interest or preconceptions. \\
& Exhibits close-mindedness or hostility to reason. \\
& Misinterprets evidence, statements, graphics, questions, etc. \\
(Unacceptable) $)$ & Fails to identify strong, relevant counter-arguments. \\
& Ignores or superficially evaluates obvious alternative points of view. \\
& Draws unwarranted or fallacious conclusions. \\
& Justifies few results or procedures, seldom explains reasons. \\
& Regardless of the evidence or reasons, maintains or defends views based \\
& on self-interest or preconceptions. \\
(Acceptable) & Accurately interprets evidence, statements, graphics, questions, etc. \\
& Identifies relevant arguments (reasons and claims) pro and con. \\
& Offers analyses and evaluations of obvious alternative points of view. \\
& Draws warranted, non-fallacious conclusions. \\
& Justifies some results or procedures, explains reasons. \\
& Fair-mindedly follows where evidence and reasons lead. \\
& Accurately interprets evidence, statements, graphics, questions, etc. \\
(Strong) & Identifies the most important arguments (reasons and claims) pro and con. \\
& Thoughtfully analyzes and evaluates major alternative points of view. \\
& Draws warranted, judicious, non-fallacious conclusions. \\
& Justifies key results and procedures, explains assumptions and reasons. \\
& Fair-mindedly follows where evidence and reasons lead. \\
\hline &
\end{tabular}

\section{DISCUSSION}

\section{Learning Process Using Hoax News as Reading Materials}

The learning process using hoax news to promote the students' critical thinking which was undergone in two cycles (7 meetings) is presented in table 2. The different topic was given for each meeting to offer the different problems and perspectives as well as to maintain the students' interest.

Table 2. The Description of Learning Process Using Hoax News as Reading Materials

\begin{tabular}{cccll}
\hline No & Cycles & Meeting & \multicolumn{1}{c}{ Date } & \multicolumn{1}{c}{ Topic } \\
\hline 1 & 1 & 1 & 28 April 2017 & Planned Parenthood Opens \\
& 2 & 4 May 2017 & $\$ 8$ Billion Abortionplex \\
\cline { 2 - 3 } & & 2 &
\end{tabular}




\begin{tabular}{llll}
\cline { 3 - 3 } 2 & 3 & 11 May 2017 & \\
& 4 & 18 May 2017 & Pokemon Go: "I am Jewish" \\
& 5 & 25 May 2017 & \\
& 6 & 1 June 2017 & Indonesia's First Disneyland \\
& 7 & 8 June 2017 & \\
\hline
\end{tabular}

During the learning process, the students were assigned into five groups to discuss the given issue within hoax news. The task has been set and informed before where students were required to determine whether the news is hoax by providing the interpretation on the evidence, statements, graphic etc; identifying the arguments; analyzing and evaluating point of view; drawing warranted, judicious, non-fallacious conclusion; justifying key result and procedure and explaining assumption and reason.

Based on the observation result, the learning process conducted in the beginning did not show the students' real ability to interpret the evidence and statements. Most of the students did not point out the evidence and arguments stated in the passage and provide the opposite evidence as well as arguments to strengthen their judgment in order to attest that the article is a hoax. Those things show the students' low ability in providing the arguments and evidence which result in the weak-proposed statements and argumentations. Moreover, some students less analyze the writer's point of view about the main topic thus they misunderstood the topic of discussion like in the first given article, Abortionplex. In discussing this topic, some students tended to talk about the abortion in general context based on their basic knowledge rather than the Abortionplex as the main point to be discussed. It showed that the students' critical thinking level was mostly unacceptable (level 2), although the critical thinking of the three to five of them were acceptable (level 3).

Through the reflection phase, it was obvious that most students got difficulties to provide opinion and discourage to communicate their ideas. The repetition of the opinion from one group to others occurred (in the first meeting). Moreover, the discussion was dominated by several students. Most students in the group categorized as passive students where they did not give significant contribution when the discussion run. Besides, based on the observation report, the internet access was a helpful aid for students to investigate the existing facts, arguments, evidence and etc. This learning aid plays significant contributions in providing broad information to examine the righteousness of the statement as well as provide the evidence, fact, statistic and others supporting statement to enhance students' opinion about the case and deciding whether the article is a hoax at the end. 
In the next cycle, there was a betterment of the students' ability in providing and communicating the ideas. The students were encouraged to deliver their opinion about the topic given (Pokemon Go: "I am Jewish" and Indonesia's First Disneyland) and communicate their ideas better by providing the supporting evidence, the fact even showing the flawed arguments in the article. They criticized the detail information stated in the news and presented their opinion in harmony. Those deep investigations showed that the students' critical thinking was improved since they attempted to drive other students to agree more with their opinion by presenting logical and reasonable supporting arguments. Moreover, the passive students have shown their role where they were given an opportunity to express their ideas about the topic in group and class. This betterment results in positive contribution since the varied point of view emerged and enrich the points of discussion which at the end develop the student's ability in identifying the arguments, analyzing and evaluating point of view, drawing the non-fallacious conclusion, explaining assumption and reason to establish their critical thinking.

Hoax news defines as a plot to trick or deceive or the object used in the deception, a fake or fabrication (Erlich, Flexner, Carruth and Hawkins, 1986), is an alternative reading material to promote the students' critical thinking. Hoaxes may be inspired for multiple reasons: to see how far it may go, harass an individual or group or damage reputation. The term "urban legend" may sound familiar. It also falls into the category of uncensored information available on the internet (Paul in Pike, 2005). Whatever label is applied, it ultimately becomes the recipients' chore to sort out the facts. The existence of the hoax news then drives the reader's interest to re-examine the truth of the news by investigating the pieces of information in the news article and link the gotten information to draw the conclusion whether the article is a hoax. This challenge then requires the students' critical thinking ability to conduct a deep investigation and understand how to critically evaluate the news content. 


\section{The Improvement of the Students' Critical Thinking}

In regard to the improvement of the students' critical thinking, the result of the pre-test and post-test conducted before and after the using of hoax news as the reading materials in figure 1 showed that there is the significant improvement of the students critical thinking.

Figure 1. The Improvement of the Students' Critical Thinking Score

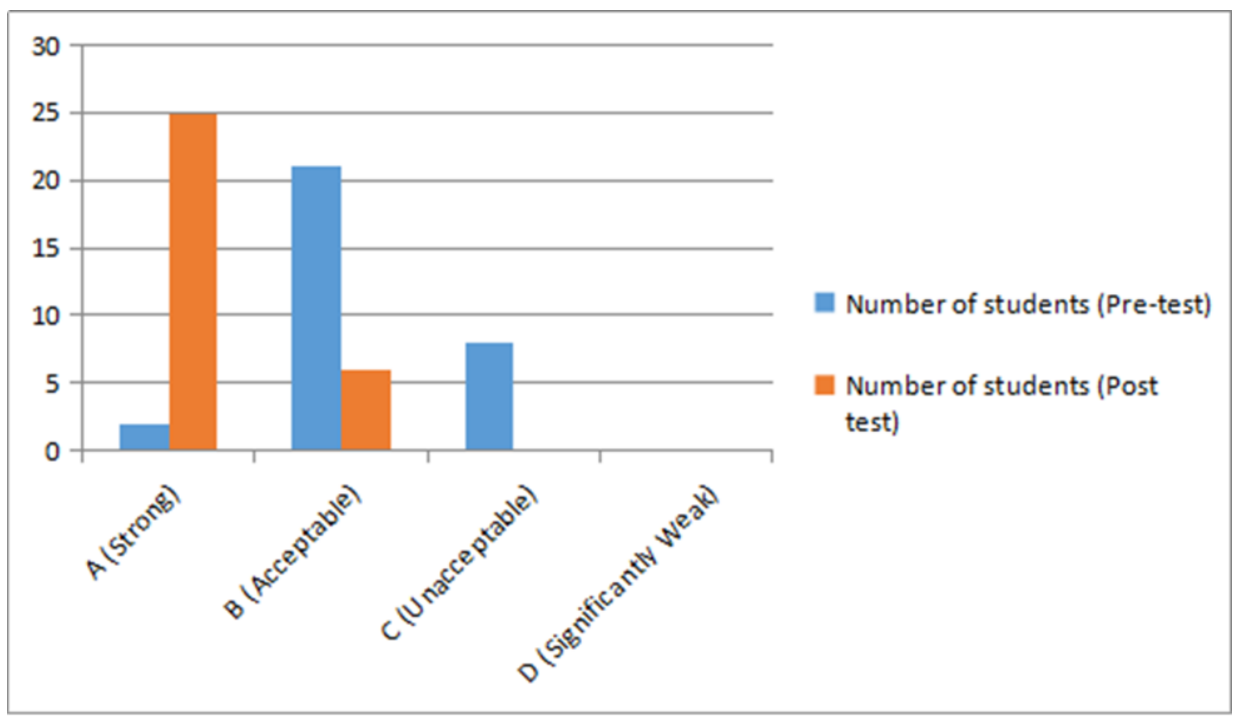

Considering the pre-test result presented in Figure 1, it shows that none student performed the significantly weak critical thinking, 8 students $(28.81 \%)$ perform unacceptable thinking, 21 students (67.74\%) show acceptable thinking and the rest, 2 students $(6.45 \%)$ present the strong thinking. Compare to the result of the post-test, the students' critical thinking is significantly developed. It was shown that none of the students was in the lowest level of the critical thinking which reflects the significantly weak and unacceptable thinking. Six students (19.35\%) performed the acceptable thinking and 25 students performed the strong thinking. It can be inferred that the number of the students who categorized in unacceptable thinking decreases $25.81 \%$ and the number of students categorized in presenting acceptable thinking also decreases $48.39 \%$. However, the number of the students possesses the strong thinking increases massively until $74.2 \%$.

The significantly weak thinking is the lowest level of thinking both displayed in verbal presentation and written report. In this level, the students presented bias interpretation to the evidence, statement, graphic, as well as detail information stated in the text. The failure in identifying the strong and relevant argument also happened. In addition, the presented 
arguments are irrelevant to the topic and unwarranted claims often stated even there is no result justification and explanation to the reason given. Last, the presented statement is lack of evidence and only based on self-interest or preconceptions. In unacceptable thinking, there is the misinterpretation with the evidence, statement, graphics and etc stated in the text. The failure in identifying the strong and relevant argument still happened. In drawing the conclusion, the unwarranted and fallacious conclusion sometimes found. However, the ability in making justification the result and explaining the reason appears in this level.

The students' critical thinking increased to the level of acceptable thinking. In this stage, the students possess the ability to interpret the evidence, statement, and graphics accurately. The identification toward the stated arguments is followed by the analyses and evaluation of the point of view done well. Thus, the warrant and precise conclusion are drawn. The flow of thinking runs smooth supported by the evidence and reasons. The strong thinking performs the highest level thinking in which it accurately interprets evidence, statements, graphics, questions, etc. The identification to the most important arguments (reason and claims) done well followed by the thoughtfulness analyzes and evaluates major alternative points of view. In this level of thinking, the warranted, judicious, non-fallacious conclusions were drawn, completed by the justification of the assumption and reasons. This flow of thinking was also fair supported by the evidence and the strong reason.

Based on the result of the post-test, the strong thinking is mostly obtained by the students after the using of hoax news. Since the strong thinking is the highest order of thinking, it is assumed that the students' critical thinking is well developed. The students are able to interpret the evidence and identify the arguments in the text then conduct analysis to examine the honesty of the news. Moreover, they make an effort to link gotten information to provide logical reasons and make a justification.

The using of hoax news in learning stimulates the students to perform the highest order thinking. Hoax tends to appear in a bombastic title so people are interested in spreading it since it is interesting to be discussed. To detect the hoax news, people need to develop critical thinking by examining the truth lies behind the news, checking the website address, investigating the fact to the trusted source, and comparing the stated information to anti hoax fan page (Aryunia and Aditomo, 2017). Moreover, fake news, news as entertainment, is just another way to speak interest and converse about meaningful topics. Fake news, foster critical 
thinking, and desire to remain informed. To be read well, fake news needs a critical lens, and this lens is what can allow the reader to be more through recipients of all types of media and information (Keeshin, 2009).

\section{CONCLUSION}

Hoax news as the reading materials provides multiple views for students as the source of discussion. The verification which leads to the judgment of hoax news requires the series process of critical thinking. Regarding the result of the study, it can be concluded that (1) the use of hoax news promotes the students' critical thinking in case the students possess better ability in interpreting, analyzing and evaluating the stated information in the article as well as link the information to draw the logical conclusion whether the article is hoax; (2) the learning process using hoax news as the reading material encourage students to think critically and actively in producing the accurate interpretation, identification, analyses as well as drawing the conclusion. The reflection phase in the study assisted the success of the learning process which was able to activate the passive students and facilitate students for having deep investigation towards the topic in the article. Moreover, the domination of students in the discussion can be reduced by the distribution of chance in expressing the ideas.

Based on the result of the study, several points are suggested as follows: (1) providing the appropriate topic of discussion for the hoax news draw the students' interest and maintain their motivation and enthusiasm to follow the discussion and (2) guiding and monitoring class discussion assists students to develop their critical thinking better since teachers' guidance stimulate students to think more critically and deeply about the problems exceedingly for the hard topic.

\section{REFERENCES}

Aditomo, Anindito and Aryunia, Rovien. (2017). Critical Thinking: Literacy in the Age of Hoax. Retrieved from http://www.ubaya.ac.id.

Alnofaie, H. (2013). A Framework for Implementing critical Thinking as a Language Pedagogy in EFL Preparatory programmes. Journal of Thinking Skills and Creativity 10 (2013) 154-158 retrieved on August 2017. 
Akin, et.al. (2014). How effective is critical reading in the understanding of scientific texts?

Turkey: Social and Behavioural Sciences ( 2015 ) 2444 - 2451

Akkaya, Kevin. (2012). The Relationship between Teachers Candidates' Critical Thinking Skills and Their Use of Reading Strategy. Social and Behavioural Sciences 797 - 801

Allcott, H. \& Gentzkow, M. (2016). Social Media and Fake News in the 2016 Election. USA: Journal of Economic Perspective ( 2017) 211 - 236.

Angelo, T.A. \& Cross, K.P. (1993). Classroom Assessment Technique: A Handbook for College Teachers, $2^{\text {nd }}$ Edition. San Francisco: Jossey-Bass.

Boese, Alex. (2008). What is A Hoax?. Retrieved from hoaxes.org

DeWaelsche, Scott A. (2015). Critical thinking, questioning and student engagement in Korean university English courses. Journal of Linguistic and Education: Nov (2015) $131-147$

Duran, E. \& Yalcintas, E. (2015). Review of The Critical Reading Education in The Primary Schools. Journal of Social and Behavioural Sciences ( 2015 ) 1560 - 1566

Erlich, E. Flexner, S., Carruth, G., \& Hawkins, J. (1986). Oxford American Dictionary (Healds College ed.). New York: Avon Books.

Facione, Peter. E and Facione, Noren., C. (1994). Holistic Critical Thinking Scoring Rubric. Millbrae: The California Academic Press. Retrieved from <http://www.insightassessment.com/pdf_files/rubric.pdf

Haromi, F. A. (2014). Teaching through Appraisal: Developing Critical Reading in Iranian EFL Learners. Journal of Social and Behavioural Sciences ( 2014 ) 127 - 136

Kamgar, N. and Jadidi, Esmaeil. (2016). Exploring the Relationship of Iranian EFL Learners' Critical Thinking and Self-regulation with their Reading Comprehension Ability. Journal of Social and Behavioural Sciences: April (2016) 776 - 783

Keeshin, J. (2009). An Examination of the Role Satirical News in Promoting Media Literature and Encouraging Engagement with Current Events. Retrieved from http://www.thekesh.docs.pwrfinal.

Kemmis, S. \& McTaggart, R. (1992). The Action Research Planner. Victoria: Deaken University Press.

Lazer, et.al. (2017). Combating Fake News: An Agenda for Research and Action. 
Pike, Ann. (2005). Dissecting an Internet Hoax: Water, Food, Plastic and Microwaves. Journal of Pediatric Nursing Nov/Dec 2005; Vol. 31No. 6

Rivas, P.G. (2017). Strategies for teaching and dissemination of artistic heritage by promoting critical and creative thinking among future Primary Education teachers. Journal of Social and Behavioural Sciences 717-722

Rubin, et.al. (2015). Deception Detection for News: Three Types of Fakes. USA: ASIST November (2015) 6-10. USA: May (2017)

Wilson, Kate. (2016). Critical reading, critical thinking: Delicate scaffolding in English for Academic Purposes (EAP). Australia: Thinking Skills and Creativity: Oct (2016) 256-265

Valerio, Anna. (2013). Translation and ideology: a critical reading. Journal of Social and Behavioural Sciences ( 2013 ) 986 - 996

Zivkovic, Sladana. (2016). A Model of Critical Thinking as an Important Attribute for Success in the 21st Century. Journal of Social and Behavioral Sciences, April (2016) $102-108$ 